\title{
Bazı Fasulye (Phaseolus vulgaris L.) Genotiplerinin Farklı Seviyelerdeki Tuz Stresine Gösterdikleri Tepkilerin İncelenmesi
}

\author{
Enes FIDAN ${ }^{1}$, Aytekin EKINCIALP ${ }^{2 *}$ \\ ${ }^{1}$ Van Yüzüncü Y1l Üniversitesi, Fen Bilimleri Enstitüsü, Bahçe Bitkileri ABD, Van, Türkiye \\ ${ }^{2}$ Van Yüzüncü Yıl Üniversitesi, Başkale MYO, Van, Türkiye \\ e-posta: aytekincialp@gmail.com
}

\begin{abstract}
Özet: $\mathrm{Bu}$ çalışmada, 20 adet farklı fasulye genotipine $25 \mathrm{mM}$ ve $50 \mathrm{mM}$ tuz (NaCI) dozları uygulanarak, tuz stresine gösterdikleri tepkilerin araştırılması amaçlanmıştır. Tuz uygulaması sulama suyu ile birlikte 4 gün arka arkaya uygulanmıştır. Çalışma sonunda fasulye genotiplerinde tuzluluğa toleransı belirlemek için 0-5 skalası, sürgün-kök uzunluğu, yaprak sayısı, sürgün çapı, sürgün yaş ve kuru ağıllıkları ve sürgünlerde besin elementi $(\mathrm{Na}, \mathrm{Ca}$ ve $\mathrm{K}$ ) içerikleri incelenmiştir. Elde edilen sonuçlara göre, genotipler arasında tuza tolerans bakımından önemli farklılıkların olduğu belirlenmiştir. 0-5 skalasına göre özellikle $50 \mathrm{mM}$ tuz dozu uygulanan grupta önemli gelişme geriliği olduğu ortaya çıkmıştır. Uygulanan tuz konsantrasyonu artışına paralel olarak sürgün boyu, yaprak sayısı, sürgün çapı, sürgün yaş ağırlığı, $\mathrm{K}, \mathrm{K} / \mathrm{Na}$ ve $\mathrm{Ca} / \mathrm{Na}$ oranlarının azaldığı; $\mathrm{Ca}$ ve Na miktarının ise arttığı tespit edilmiştir.
\end{abstract}

Anahtar kelimeler: Besin elementi, fasulye, genotip, $\mathrm{NaCI}$

\section{Investigation of Responses of Some Bean (Phaseolus vulgaris L.) Genotypes to Different Levels of Salt Stress}

\begin{abstract}
In this study, it was aimed to investigate the responses of 20 different bean genotypes to different levels of salt stress. In the study, the reactions of 20 different bean genotypes at $25 \mathrm{mM}$ and $50 \mathrm{mM} \mathrm{NaCI}$ were investigated. Salt application was carried out for 4 consecutive days with irrigation water. At the end of the study, 0-5 scale, number of leaves, shoot diameter, shoot length, shoot dry and fresh weights and nutrient elements (Na, $\mathrm{Ca}$ and $\mathrm{K}$ ) in the bean genotypes were determined in order to determine the tolerance to salinity. According to the results obtained at the end of the study, it was determined that there were significant differences in tolerance between the genotypes. According to the scale $0-5$, it was found that there was significant developmental retardation especially in the group receiving $50 \mathrm{mM}$ salt dose. In parallel with the increase of applied salt concentration, the shoot size, leaf number, shoot diameter, shoot age weight, $\mathrm{K}, \mathrm{K} / \mathrm{Na}$ and $\mathrm{Ca} / \mathrm{Na}$ ratio decreased; $\mathrm{Ca}$ and $\mathrm{Na}$ content were increased.
\end{abstract}

Keywords: Nutrients, bean, genotype, $\mathrm{NaCl}$

\section{Giriş}

Baklagiller arasında en çok yetiştiriciliği yapılan fasulyenin anavatanı Meksika, Guatemala, Kolombiya, Orta ve Güney Amerika ülkeleri olduğu bilinmektedir (Şalk ve ark. 2008). Fasulyenin Türkiye'ye ne zaman ve kimin tarafından getirildiği kesin olarak bilinmemesinin yanında, 17. yüzyılda ülkemizde yetiştiriciliği yapıldı̆̆ tahmin edilmektedir (Bozoğlu ve Sözen 2007). Türkiye, fasulyenin gen merkezleri arasında bulunmamasına rağmen zengin bir genetik çeşitliliğe sahiptir. Fasulye genotiplerinin, gerek tüketim özellikleri, gerekse morfolojik olarak geniş bir varyasyon gösterdiği, daha önce yapılan birçok çalışma ile ortaya çıkarılmıştır (Balkaya 1999; Sözen 2006).

Ülkemizdeki toprak tuzluluğu sulu tarım alanlarında bilinçsiz sulamanın yapılması, sulama suyu kalitesinin bilinmemesi yani fazla miktarda tuz içeren sular ile yapılan sulamalardan kaynaklanmakta olup ülkemizde 1.5 milyon hektar alanda tuzluluk problemi bulunmaktadır (Kaplan ve Kara 2014, Çakmakcı ve ark. 2016). Toprakta bulunan çözünebilir tuzların miktarı, bitkinin büyümesi ve gelişmesi için gerekli olan miktarın üzerine çıktı̆̆ında sorunlar ortaya çıkmaya başlamakta ve toprakta tuz miktarı arttıkça da bitkinin su alımı engellenmektedir. Tuz konsantrasyonu, kullanılabilir su potansiyelini düşürmeye yetecek kadar olduğunda (0.5-1.0 bar) bitki strese girer ki, bu da tuz stresi olarak adlandırılır (Levitt 1980). Diğer bitki türleriyle kıyaslandığında, baklagiller tuzluluğa en hassas grup içinde yer almakta ve fasulye'nin tuza en hassas türlerden olduğu bildirilmektedir 
(Ashraf ve Wu 1994). Yüksek tuz oranı, fasulyede çimlenmeyi olumsuz yönde etkilemektedir (Demir ve Demir 1996). Bitkilerdeki tuzluluğun olumsuz etkilerini ortadan kaldırmak için yapılabilecek uygulamalardan biri, toprakta biriken tuzların yıkanarak uzaklaştırılmasıdır. Fakat bu yöntemin maliyetinin yüksek olmasından dolayı tercih edilmemektedir. Bu problemin çözümünde yapılacak diğer bir çözüm yolu ise tuza dayanaklı bitki tür ve çeşitlerinin yetiştirilmesidir (Khalid ve ark. 2001). Tuzlu toprakların iyileştirilmesi için uygulanan 1slah yöntemleri zaman alıcı ve oldukça yüksek maliyetli olduğundan; bu alanlarda yetişebilen, tuzluluğa dayanıklı, ekonomik olarak yetiştirilebilecek bitki tür veya çeşitlerinin geliştirilerek kullanılması önem arz etmektedir (Ashraf ve Wu 1994).

$\mathrm{Bu}$ çalışmada bazı fasulye genotiplerinin tuz konsantrasyonuna karşı gösterdikleri tepkilerin araştırılması amaçlanmıştır.

\section{Materyal ve Yöntem}

\section{Bitkisel Materyal}

Araştırmada kullanılan bitkisel materyallerden 19 ve 20 no'lu genotipler Bitlis-Adilcevazdan, diğer genotiplerin tamamı Anadolu Tarımsal Araştırma Enstitüsünün gen havuzundan temin edilmiştir (Çizelge 1).

Çizelge 1. Çalışmada kullanılan fasulye genotiplerine ait kimlik bilgileri

\begin{tabular}{|c|c|c|}
\hline Genotip No & Temin Edildiği Yer & Bitki Görünümü \\
\hline 1 & Anadolu Tarımsal Araştırma Enstitüsü & Bodur \\
\hline 2 & Anadolu Tarımsal Araştırma Enstitüsü & Sirık \\
\hline 3 & Anadolu Tarımsal Araştırma Enstitüsü & Sirık \\
\hline 4 & Anadolu Tarımsal Araştırma Enstitüsü & Sirık \\
\hline 5 & Anadolu Tarımsal Araştırma Enstitüsü & Sirık \\
\hline 6 & Anadolu Tarımsal Araştırma Enstitüsü & Sirık \\
\hline 7 & Anadolu Tarımsal Araştırma Enstitüsü & Sirık \\
\hline 8 & Anadolu Tarımsal Araştırma Enstitüsü & Bodur \\
\hline 9 & Anadolu Tarımsal Araştırma Enstitüsü & Bodur \\
\hline 10 & Anadolu Tarımsal Araştırma Enstitüsü & Sirık \\
\hline 11 & Anadolu Tarımsal Araştırma Enstitüsü & Bodur \\
\hline 12 & Anadolu Tarımsal Araştırma Enstitüsü & Sirık \\
\hline 13 & Anadolu Tarımsal Araştırma Enstitüsü & Sirık \\
\hline 14 & Anadolu Tarımsal Araştırma Enstitüsü & Sirık \\
\hline 15 & Anadolu Tarımsal Araştırma Enstitüsü & Sirık \\
\hline 16 & Anadolu Tarımsal Araştırma Enstitüsü & Bodur \\
\hline 17 & Anadolu Tarımsal Araştırma Enstitüsü & Sirık \\
\hline 18 & Anadolu Tarımsal Araştırma Enstitüsü & Bodur \\
\hline 19 & Bitlis-Adilcevaz & Sirık \\
\hline 20 & Bitlis-Adilcevaz & Bodur \\
\hline
\end{tabular}

\section{Tuz Uygulanmasl ve Deneme Deseni}

25 ve $50 \mathrm{mM} \mathrm{NaCl}$ konsantrasyonları kullanılmıştır. Denemenin kurulma aşamasında, 2:1 oranında torf-perlit harcı ile doldurulmuş 3 litre hacimli saksılara tohum ekimi yapılmış ve tohumların üzeri vermikülitle kapatılmıştır. Tesadüf parselleri deneme desenine göre 3 tekerrürlü ve her tekerrürde 3 bitki olacak şekilde tasarlanan çalışma, $23 \pm 2{ }^{\circ} \mathrm{C}$ sıcaklık ve 8000 lüx 1şı şiddetinde iklimlendirme odası koşullarında yürütülmüştür. Kotiledon yaprakları yatay duruma gelen ve ilk gerçek yaprakları görülmeye başlayan fidelere, bir defa olmak üzere Hougland besin çözeltisi uygulanmıştır (Kaya 2011). Bitkiler 3 yapraklı aşamaya ulaşıncaya kadar stressiz koşullarda büyütülmüş, bu aşamadan sonra tuz stresine maruz bırakılmıştır. Tuz uygulaması, 4 gün boyunca her gün aynı saatte sulama suyu ile birlikte yapılmıştır.

\section{İncelenen özellikler}

Genotiplerin görsel olarak değerlendirilmesi (0-5 skalası)

0: Hiç etkilenme yok (kontrol bitkileri), 1: Tuz stresinden hafif etkilenme \% 5'den fazla değil, 2: Alt yapraklarda solgunluk başlangıcı ve tuz stresinden etkilenme \% 6-20 arası olabilir, 3: Yapraklarda kıvrılma, kapanma, solgunluk ve sararmalar \% 21-50 arası stresten etkilenme olabilir, 4: Yaprakların \% 51-80 düzeylerinde şiddetli 
solgunluk, sararma, yapraklarda nekroz ve kurumalar, 5: Bitkide \% 80 üzerinde geriye dönüşümsüz solma, yapraklarda kurumalar veya ölüm olabilir. (Kuşvuran 2010).

\section{Fide gelissim parametrelerinin belirlenmesi}

Sürgün çapının belirlenmesi: Bitkilerin kök boğazının $2 \mathrm{~cm}$ üst gövde bölgesi dijital kumpasla ölçülerek belirlenmiştir.

Sürgün ve kök uzunluklarının belirlenmesi: Sürgün boyu, bitkilerin kök boğazından büyüme ucuna kadar olan bölge, kök boyu ise kök boğazından kök ucuna kadar olan bölge olmak üzere şerit metre yardımı ile tespit edilmiştir.

Yaprak sayısının belirlenmesi: Her tekerrürde, üç bitki üzerindeki yaprak sayılarının ortalamaları alınmıştır.

Sürgünlerde yaş ve kuru ağırlıkların belirlenmesi: Deneme sonucunda tesadüfî olarak seçilen her tekerrürdeki üç bitki, hassas terazi de tartılarak $( \pm 0.1 \mathrm{~g})$ yaş ağırlıkları belirlenmiştir, daha sonra aynı örnekler $65-70^{\circ} \mathrm{C}$ etüvde 48 saat kurutulduktan sonra kuru ağırlıkları belirlenmiştir.

Sürgünlerde besin elementi analizi: Sürgünlerde besin elementi analizi yaş yakma yöntemiyle belirlenmiştir. Kurutulan bitkilerin sürgünlerinden $0.2 \mathrm{~g}$ tartılı şaletlere konularak üzerine $6 \mathrm{ml}$ nitrik asit (\%65'lik) ve $2 \mathrm{ml}$ hidrojen peroksit eklenerek 200 C'lik mikrodalga cihazında 45 dakika yakılarak besin elementi analizi için hazırlanmıştır. $\mathrm{Ca}$, K, ve $\mathrm{Na}$ elementleri Atomik Absorpsiyon Spektrofotometre cihazında okunmuştur. (Kimbrough ve Wakakuwa 1989).

\section{Istatistiksel Analiz}

Araştırmada elde edilen veriler, tesadüf parselleri deneme desenine göre, varyans analizi ile $P<0.05$ önemlilik derecesine göre değerlendirilmiştir. Verilerin analizinde istatistiksel olarak önemli bulunan ortalamalar "Duncan Çoklu Karşılaştırma Testi”ne göre gruplandırılmıştır (Düzgüneş ve ark. 1987). Elde edilen verilerin analizinde, SPSS paket programı kullanılmıştır.

\section{Bulgular ve Tartışma}

\section{Fide gelişim parametrelerinde ortaya çıkan değişimler}

Birçok araştırmacı, tuzluluk üzerine yaptıkları çalışmalarında, skala değerleri için genotip seçiminin önemli bir parametre olabileceğini belirtmişlerdir (Aktaş 2002; Daşgan ve ark. 2002; Koç 2005). Bitkilerdeki tuz stresinden kaynaklanan zararlanmanın belirtilerini belirlemek amacıyla yapılan 0-5 skala değerlendirmesi genel ortalama üzerinden incelendiğinde, fasulye genotiplerinin \% 6-20 arasında tuz stresinden etkilendikleri görülmektedir. 25 $\mathrm{mM}$ tuz dozunun oluşturduğu zararın etkisi $\% 5$ olarak, $50 \mathrm{mM}$ tuz dozunun oluşturduğu zararın etkisi ise $\% 21$ 50 olarak tespit edilmiştir. $25 \mathrm{mM}$ tuz dozunda en fazla zararlanma \% 6-20 arasında olan 3 no'lu genotipte belirlenmiş olup bunu sırası ile 4, 6 ve 7 no'lu genotipler takip etmiştir. En az zararlanma ise \% 5 'in altında değerleri alan $1,11,15$ ve 16 no'lu genotiplerde ortaya çıkmıştır. $50 \mathrm{mM}$ tuz dozunda en fazla zararlanma \% 100 ile 14 ve 18 no'lu genotiplerde; en az zararlanma ise \% 6-20 ile 10 no'lu genotipte ortaya çıkmış ve bunu sırasıyla 19 ve 2 no'lu genotipler takip etmiştir (Çizelge 2).

Tuz uygulaması altında yetiştirilen fasulyede (Kaya 2011), kavunda (Kuşvuran 2010) ve birçok bitki türünde tuz uygulamasının sürgün uzunluğu üzerine olumsuz etkilerinin olduğu bildirilmiştir. Yürütmüş olduğumuz çalışmamız sonucunda da, tuz dozunun artmasıyla birlikte, fasulye genotipleri tuz stresinden etkilenmiş ve sürgün boyu değerlerinde azalmalar ortaya çıkmıştır. Sürgün boyunda uygulamalar arasında elde edilen farklılıklar, istatistiksel olarak önemli bulunmuştur. Çalışmamızda, $25 \mathrm{mM}$ tuz uygulamasında, kontrol grubuna göre \% değişim oranları bakımından sürgün boyunda olumsuz yönden en fazla etkilenen \% -51.74 ile 16 no'lu genotip olurken en az etkilenen ise \% -2.45 ile 12 no'lu genotip olmuştur. 5 ve 13 no'lu genotipler ise tuz stresinden olumlu yönden etkilenerek sürgün boyunda artış saptanmıştır. $50 \mathrm{mM}$ tuz uygulamasında, kontrol grubuna göre \% değişim oranları bakımından ise en fazla etkilenen \% -69.53 ile 14 no'lu genotip olurken en az etkilenen genotip ise \% -2.10 ile 5 no'lu genotip olmuştur. Tuz stresi altında yetiştirilen bitkilerde, genellikle stresin sürgün uzunluğu üzerine olumsuz etkilerinin olduğu fakat bu etkilerin genotipler arasında değişiklikler içerdiği belirtilmiştir (Kaya 2011; Güldüren 2012). 
Çizelge 2. Farklı tuz dozları sonunda genotiplerde 0-5 skalasına ait ortalama değerler

\begin{tabular}{llllllll}
\hline \multicolumn{7}{c}{ Skala Değerleri } \\
\hline Genotip & $25 \mathrm{mM}$ & $50 \mathrm{Mm}$ & Ort & Genotip & $25 \mathrm{mM}$ & $50 \mathrm{Mm}$ & Ort \\
\hline 1 & $\mathbf{1 . 0 0}$ & 2.76 & 1.88 & 11 & $\mathbf{1 . 0 0}$ & 4.20 & 2.60 \\
2 & 1.20 & $\mathbf{2 . 0 0}$ & 1.10 & 12 & 1.10 & 3.10 & 2.10 \\
3 & 2.00 & 4.53 & 3.26 & 13 & 1.20 & 4.16 & 2.68 \\
4 & 1.86 & 3.86 & 2.86 & 14 & $\mathbf{1 . 5 3}$ & 5.00 & 3.26 \\
5 & 1.63 & 2.96 & 2.29 & 15 & $\mathbf{1 . 0 0}$ & 2.40 & 1.70 \\
6 & $\mathbf{1 . 7 3}$ & 3.20 & 2.46 & 16 & $\mathbf{1 . 0 0}$ & 2.50 & 1.75 \\
7 & $\mathbf{1 . 7 3}$ & 4.43 & 3.08 & 17 & 1.20 & 2.93 & 2.05 \\
8 & 1.40 & 2.30 & 1.85 & 18 & 1.10 & 5.00 & 3.05 \\
9 & 1.30 & 2.20 & 1.75 & 19 & 1.20 & $\mathbf{1 . 7 6}$ & 1.48 \\
10 & 1.33 & $\mathbf{1 . 6 6}$ & 1.49 & 20 & 1.10 & 4.33 & 2.71 \\
\hline Genel Ortalama & & & & 1.33 & 3.26 & 2.27 \\
\hline
\end{tabular}

Çalışmamızda $25 \mathrm{mM}$ tuz stresinde 5 ve 13 numaralı genotiplerin sürgün boylarında azalmalar meydana gelmemiş olup, $50 \mathrm{mM}$ tuz dozunda ise tüm genotiplerin olumsuz etkilendikleri belirlenmiştir. (Çizelge 3). Seymen ve Önder (2015), kuru fasulye üzerinde yaptıkları bir tuzluluk çalışmasında, tuz uygulamalarının kontrole göre yüzdelik değişimlerinin kök uzunluğu açısından \% 40'a varan kayıpları ortaya koyduğunu ve bazı genotiplerde ise $\%$ değişimlerinin olumlu olarak tespit edildiğini belirtmişlerdir. Bizim yürüttüğümüz çalışmada, $25 \mathrm{mM}$ tuz uygulamasının kontrol grubu \% değişim oranlarına göre kök boyunda en fazla etkilenen \% -15.62 ile 13 no'lu genotip olurken en az etkilenen ise \% -2.07 ile 10 no'lu genotip olduğu gözlenmiştir. Diğer tüm genotiplerin kök boyu tuz stresine karşı olumsuz yönde etkilenmemişlerdir. $50 \mathrm{mM}$ tuz uygulamasının kontrol grubu \% değişim oranlarına göre en fazla etkilenen sırasıyla ile 19 (\%-18.88) ve 16 no'lu (\% -12.22) genotipler olurken en az etkilenen ise \% -1.35 ile 5 no'lu genotip olduğu tespit edilmiştir. Diğer tüm genotiplerin kök boyları tuz dozlarından olumsuz etkilenmemişlerdir (Çizelge 3).

Tuz stresi genel olarak yaprak alanında ve sayısında azalma, büyümede de yavaşlatıcı bir etki meydana getirmektedir (Kaya 2011). Seymen ve Önder (2015), 28 kuru fasulye genotipi üzerinde yaptıkları tuzluluk çalışmasında, kontrole göre değişim oranlarında sadece bir genotipte ki yaprak sayısında artış meydana gelmiş, diğer genotiplerin tümünün yaprak sayılarında azalmalar meydana gelmiştir. Çalışmamızda, yaprak sayısında, uygulamalar ve genotipler arasında elde edilen farkl1lıklar istatistiksel olarak önemli bulunmuştur. $25 \mathrm{mM}$ tuz uygulamasının kontrol grubu \% değişim oranlarına göre yaprak sayısında en fazla etkilenen \% -28.57 ile 16 no'lu genotip; en az etkilenen ise \% -3.93 ile 5 no'lu genotip olmuştur. $2,4,7,8,11,12,13$ ve 15 no'lu genotipler olumsuz yönde etkilenmemișlerdir. $50 \mathrm{mM}$ tuz uygulamasının kontrol grubu \% değișim oranlarına göre tüm genotiplerin yaprak sayısında azalmalar meydana gelmiş ve en fazla etkilenen \% -55.55 ile 19 no'lu genotip; en az etkilenen ise \% -9.09 ile 17 no'lu genotip olmuştur. Kuşvuran (2010), kavunda yaptığı tuzluluk çalışmasında, tuz uygulamalarının yaprak sayısında \% 21-72 oranında azalmalar meydana getirdiğini belirtmiştir. Lutts ve ark. (1996), ise aksi yönde, tuz stresi sonucu kontrol bitkilerine oranla bitkilerin yaprak sayılarında bir farklılık meydana gelmediğini bildirmişlerdir. Çalışmamızda, her iki tuz dozunda yaprak sayılarında azalmalar meydana gelmiş fakat $25 \mathrm{mM}$ tuz dozunda tolerant gösteren genotipler ortaya çıktığı tespit edilmiş̧ir (Çizelge 3).

Seemann ve Critchley (1985), fasulye üzerinde $150 \mathrm{Mm}$ tuz uygulaması sonucunda, bitki yaş ve kuru ağırlıklarında azalmalar olduğunu belirtmiş̧lerdir. Çalışmamızda, sürgün yaş ağırlığında uygulamalar ve genotipler arasında elde edilen farklılıklar istatistiksel olarak önemli bulunmuştur. $25 \mathrm{mM}$ tuz uygulamasının kontrol grubu \% değişim oranlarına göre sürgün yaş ağırlığında 2, 4, 7, 8, 11, 12, 17 ve 19 no'lu genotiplerin dışındaki genotiplerde azalmalar meydana gelmiş ve en fazla etkilenen \%-34.78 ile 13 no'lu genotip; en az etkilenen ise \% -8.55 ile 6 no'lu genotip olmuştur.

$50 \mathrm{mM}$ tuz uygulamasının kontrol grubu \% değişim oranlarına göre sürgün yaş ağılı̆ı̆ında tüm genotipler tuzluluktan olumsuz etkilenmiş ve en fazla etkilenen \% -74.22 ile 18 no'lu genotip; en az etkilenen ise $\%-1.79$ ile 8 no'lu genotip olmuştur (Çizelge 4). Debouba ve ark. (2006), tuz konsantrasyonundaki artışa bağlı olarak domates bitkilerinin kuru ağırlık değerlerinde azalma meydana geldiğini belirtirken, Kaymakanova ve Stoeva (2008), fasulyede yaptıkları çalışmada tuz uygulamalarının bitki gelişimine olumsuz etki yaparak, yaş ve kuru ağırlıklarda azalmaya neden olacağını belirtmişlerdir. Başka çalışmalarda da, tuz uygulamalarının bitkilerde yeşil aksam yaş ağırlığına paralel olarak yeşil aksam kuru ağırlıklarına da olumsuz etkileri olduğu bildirilmektedir (Demir 2009; Güldüren 2012). Çalışmamızda sürgün kuru ağırlığında, uygulamalar arasında istatistiksel olarak elde edilen farklılıklar önemli çıkmış ve sürgün kuru ağırlığı bakımından olumsuz etkilenen genotiplerin yanında, olumlu yönde etkilenen genotipler de belirlenmiştir. $25 \mathrm{mM}$ tuz uygulamasının kontrol 
grubu \% değişim oranlarına göre sürgün kuru ağırlığında en fazla olumsuz olarak etkilenen \% -26.02 ile 1 no'lu genotip; en az etkilenen ise \% -5.30 ile 20 no'lu genotip; $50 \mathrm{mM}$ tuz uygulamasinda ise olumsuz olarak en fazla etkilenen \% -26.96 ile 5 no'lu genotip; en az etkilenenin ise \% -8.12 ile 10 no'lu genotip olduğu tespit edilmiştir (Çizelge 4).

Sürgün çapında hem uygulamalarda hem de genotipler arasında istatistiksel olarak önemli farklılıkların olduğu belirlenmiştir. $25 \mathrm{mM}$ tuz uygulamasının kontrol grubu \% değişim oranlarına göre, 4 ve 17 no'lu genotiplerin sürgün çapları olumsuz olarak etkilenmez iken, diğer genotiplerde azalmalar meydana gelmiştir. Sürgün çapı en fazla etkilenen \% -18.61 ile 18 no'lu genotip olurken en az etkilenen ise \% -0.30 ile 8 no'lu genotip olduğu gözlenmiştir. $50 \mathrm{mM}$ tuz uygulamasında tüm genotiplerin sürgün çapında azalmalar gözlenmiş ve en fazla etkilenen \% -32.50 ile 14 no'lu genotip; en az etkilenen ise \% -3.14 ile 4 no'lu genotip olmuştur (Çizelge 4). Neves ve ark. (2004), pirinçte tuz stresi karşısında bitki çapında azalmalar meydana gelebileceğini, Lacerda ve ark. (2003), sorgumda tuz stresinin gövde gelişimini azalttığını, Takagi ve ark. (2009) domateste tuz stresinin bitki gelişiminde olumsuzluklara neden olduğunu, bitki çapında da azalmaya yol açtığını bildirmiştir. Çalışmamızda, önceki yapılan çalışmalara paralel olarak $25 \mathrm{Mm}$ tuz dozunda 4 ve 17 no'lu genotiplerin dişında ve $50 \mathrm{mM}$ dozunda tüm bitkilerde azalmalar meydana gelmiştir. Fakat $25 \mathrm{Mm}$ tuz dozundan olumsuz yönde etkilenmeyen 4 no'lu genotipin $50 \mathrm{mM}$ tuz dozundan da en az etkilenen olarak ortaya çıması bu genotipin önemliliğini ortaya koymaktadır.

\section{Sürgünlerde besin elementi içerikleri}

Tuz stresinin sürgünlerde $\mathrm{Na}$ içeriğine etkisinden elde edilen farklılıklar, uygulamalar arasında istatistiksel olarak önemli bulunurken, genotipler arasında önemsiz bulunmuştur. $25 \mathrm{mM}$ tuz dozu uygulamasında 4 no'lu genotip dışında ve $50 \mathrm{mM}$ tuz dozu uygulamasında tüm genotiplerde Na artışı gözlenmiştir (Çizelge 5). Ashraf ve ark. (2003) bamyada Debouba ve ark. (2006), domateste yaptıkları çalışmalarda yapılan tuz uygulamaları karşısında bitki bünyesinde $\mathrm{Na}$ iyonunda artışlar meydana geldiğini, Tiwari ve ark. (2010), artan tuz konsantrasyonunun, hıyarda $\mathrm{Na}$ içeriğinin artmasını sağlarken tolerant olan genotiplerin bünyelerine daha az oranda $\mathrm{Na}$ aldığını bildirmişlerdir. Yaptığımız çalışmada daha önce yapılan çalışmaların verileri ile uyum göstermektedir.

Tuz stresinin sürgünlerde Ca içeriğine etkisinden elde edilen farklılıklar, uygulamalar arasında istatistiksel olarak önemli bulunurken, genotipler arasında önemsiz bulunmuştur. $25 \mathrm{mM}$ tuz uygulamasının kontrol grubu \% değişim oranlarına göre sürgünlerdeki Ca konsantrasyonundan en fazla etkilenen genotipler sırasıyla, 13, 16 ve 9 no'lu genotipler (\% -9.58, -6.66 ve -1.67) olmuştur. Bu üç genotip dışındaki genotiplerde Ca oranında artışlar oluşmuştur. $50 \mathrm{mM}$ tuz uygulamasında ise tüm genotiplerde artışlar tespit edilmiştir (Çizelge 5). Yapılan bir çalışmada tuz dozlarının etkisinin önemli olduğunu, tuz dozu arttıkça bitkide Ca içeriğinin arttığını saptamıştır (Kant 2008). Toprak içeriğindeki sodyumun içeriğinin artışı, bitkilerde $\mathrm{Ca}^{+}, \mathrm{K}^{+}$ve $\mathrm{Mg}^{+}$eksikliğine neden olmakta, bunun yanında toprak içeriğindeki $\mathrm{Ca}^{+}$miktarının yeterli olması durumunda ise $\mathrm{Na}^{+}$iyonunun toksik etkisi azalmaktadır (Kıpçak ve Erdinç 2016).

Ashraf ve ark. (2003), bamyada yaptıkları tuzluluk çalışmasında yüksek $\mathrm{NaCl}$ dozunun bitkilerin kök ve gövde kısımlarında $\mathrm{Na}$ ve $\mathrm{Cl}$ iyonlarında artışa neden olurken, K konsantrasyonunda azalmaların meydana geldiğini belirtmişlerdir. Tuz stresi koşullarında tüm kavun genotiplerinin yeşil aksam ve kök bölgesindeki K konsantrasyonunda azalma ortaya çıkmakta, fakat ortaya çıkan bu etki, yeşil aksamda daha belirgin bir şekilde ortaya çıkmaktadır (Kuşvuran 2010). Debouba ve ark. (2006), domateste artan NaCl dozuna bağlı olarak domates bitkisinin yaprak ve kökünde $\mathrm{K}$ iyon konsantrasyonlarında azalmaların olduğunu bildirmişlerdir. Çalışmamızda ortaya konulan sonuçlar araştırıcıların bulguları ile paralellik göstermiş olup, tuz dozu arttıkça K miktarının 10 ve 11 no'lu genotipler dışında azalmalar gösterdiği belirlenmiştir. $25 \mathrm{mM}$ tuz uygulamasının kontrol grubu \% değişim oranlarına göre 10 ve 11 no'lu genotiplerde artışlar gözlenirken, sürgünlerdeki K konsantrasyonundan en çok azalma \% -24.66 ile 7 no’lu genotipde, en düşük ise \% -5.20 ile 8 no’lu genotipde belirlenmiştir. $50 \mathrm{mM}$ doz içeren tuz uygulamasında ise tüm genotiplerde azalmalar meydana gelmiş ve en fazla etkilenen $\%-36.79$ ile 7 no'lu genotip iken en az etkilenen ise \% -4.17 ile 10 no'lu genotip olmuştur (Çizelge 5). 
Çizelge 3. Farklı tuz dozları sonunda genotiplerde sürgün boyu, kök boyu, yaprak sayısı ve kontrole göre değişimleri (\%)

\begin{tabular}{|c|c|c|c|c|c|c|c|c|c|c|c|c|c|c|c|}
\hline \multicolumn{6}{|c|}{ Sürgün Boyu (cm) } & \multicolumn{5}{|c|}{ Кӧk Воуи (cm) } & \multicolumn{5}{|c|}{ Yaprak sayısı (adet/bitki) } \\
\hline Genotip & Kontrol & $25 \mathrm{mM}$ & $25 \mathrm{mM} \%$ & $50 \mathrm{mM}$ & $50 \mathrm{mM} \%$ & Kontrol & $25 \mathrm{mM}$ & $25 \mathrm{mM} \%$ & $50 \mathrm{mM}$ & $50 \mathrm{mM} \%$ & Kontrol & $25 \mathrm{mM}$ & $25 \mathrm{mM} \%$ & $50 \mathrm{mM}$ & $50 \mathrm{mM} \%$ \\
\hline 1 & $18.11 \mathrm{~d}$ & $14.11 \mathrm{fg}$ & -22.08 & $14.88 \mathrm{e}-\mathrm{g}$ & -17.83 & $25.44 \mathrm{a}-\mathrm{d}$ & $27.44 a$ & 7.86 & $26.12 \mathrm{~cd}$ & 2.67 & $6.67 \mathrm{~cd}$ & $5.67 \mathrm{ef}$ & -14.99 & $4.33 \mathrm{c}-\mathrm{e}$ & -35.08 \\
\hline 2 & $57.71 \mathrm{a}-\mathrm{c}$ & $52.55 \mathrm{a}-\mathrm{c}$ & -8.94 & $43.00 \mathrm{a}$ & -25.51 & $25.28 \mathrm{a}-\mathrm{d}$ & $28.11 \mathrm{a}$ & 11.19 & $26.33 \mathrm{~cd}$ & 4.15 & $6.71 \mathrm{~cd}$ & $7.33 \mathrm{a}-\mathrm{d}$ & 9.23 & $4.25 \mathrm{c}-\mathrm{e}$ & -36.66 \\
\hline 3 & $57.00 \mathrm{bc}$ & $44.33 \mathrm{~cd}$ & -22.22 & $38.11 \mathrm{a}$ & -33.14 & $27.44 \mathrm{a}-\mathrm{c}$ & $29.77 \mathrm{a}$ & 8.49 & $28.22 \mathrm{~b}-\mathrm{d}$ & 2.84 & $6.67 \mathrm{~cd}$ & $6.33 c-f$ & -5.09 & $5.00 \mathrm{~b}-\mathrm{d}$ & -25.03 \\
\hline 4 & $72.25 \mathrm{a}$ & $44.12 \mathrm{~cd}$ & -38.93 & $46.88 \mathrm{a}$ & -35.11 & $25.50 \mathrm{a}-\mathrm{d}$ & $28.87 \mathrm{a}$ & 13.21 & $26.66 \mathrm{~cd}$ & 4.54 & $5.38 \mathrm{~d}$ & 5.75 ef & 6.87 & $4.33 \mathrm{c}-\mathrm{e}$ & -19.51 \\
\hline 5 & $47.50 \mathrm{bc}$ & $50.66 \mathrm{a}-\mathrm{c}$ & 6.65 & $46.50 \mathrm{a}$ & -2.10 & $27.37 \mathrm{a}-\mathrm{c}$ & $28.11 \mathrm{a}$ & 2.70 & $27.00 \mathrm{~b}-\mathrm{d}$ & -1.35 & $7.63 \mathrm{a}-\mathrm{d}$ & $7.33 \mathrm{a}-\mathrm{d}$ & -3.93 & $6.13 \mathrm{ab}$ & -19.65 \\
\hline 6 & $46.50 \mathrm{bc}$ & $28.33 \mathrm{e}$ & -39.07 & $27.00 \mathrm{~b}-\mathrm{d}$ & -41.93 & $25.00 \mathrm{a}-\mathrm{d}$ & $35.22 \mathrm{a}$ & 40.88 & $32.37 \mathrm{a}-\mathrm{c}$ & 29.48 & $7.63 \mathrm{a}-\mathrm{d}$ & 7.00 a-e & -8.25 & $5.38 \mathrm{~b}-\mathrm{d}$ & -29.48 \\
\hline 7 & $56.25 b c$ & $54.50 \mathrm{a}-\mathrm{c}$ & -3.11 & $43.00 \mathrm{a}$ & -23.55 & $23.37 \mathrm{~b}-\mathrm{d}$ & $30.12 a$ & 28.88 & $32.12 \mathrm{a}-\mathrm{c}$ & 37.44 & $5.75 \mathrm{~d}$ & $6.63 \mathrm{~b}-\mathrm{e}$ & 15.30 & $5.00 \mathrm{~b}-\mathrm{d}$ & -13.04 \\
\hline 8 & $44.33 \mathrm{c}$ & $28.00 \mathrm{e}$ & -36.83 & $24.22 \mathrm{~b}-\mathrm{e}$ & -45.36 & $25.66 \mathrm{a}-\mathrm{d}$ & $31.33 \mathrm{a}$ & 22.09 & $32.33 \mathrm{a}-\mathrm{c}$ & 25.99 & $6.67 \mathrm{~cd}$ & $8.00 \mathrm{ab}$ & 19.94 & $5.33 \mathrm{~b}-\mathrm{d}$ & -20.08 \\
\hline 9 & $14.11 d$ & $10.77 \mathrm{~g}$ & -23.67 & $10.12 \mathrm{fg}$ & -28.27 & $22.11 \mathrm{~cd}$ & $28.66 \mathrm{a}$ & 29.62 & $25.28 \mathrm{~cd}$ & 14.33 & $5.67 \mathrm{~d}$ & $5.00 \mathrm{f}$ & -11.81 & $3.13 \mathrm{e}$ & -44.79 \\
\hline 10 & $52.44 \mathrm{bc}$ & $34.11 \mathrm{de}$ & -34.95 & $28.00 b c$ & -46.60 & $32.22 \mathrm{a}$ & $31.55 \mathrm{a}$ & -2.07 & $34.11 \mathrm{ab}$ & 5.86 & $9.33 \mathrm{a}$ & $7.67 \mathrm{a}-\mathrm{c}$ & -17.79 & $6.78 \mathrm{a}$ & -27.33 \\
\hline 11 & $15.12 \mathrm{~d}$ & $14.33 \mathrm{fg}$ & -5.22 & $10.33 \mathrm{fg}$ & -31.67 & $17.87 \mathrm{~d}$ & $27.11 \mathrm{a}$ & 51.70 & $28.00 \mathrm{~b}-\mathrm{d}$ & 56.68 & $5.75 \mathrm{~d}$ & $6.00 \mathrm{~d}-\mathrm{f}$ & 4.34 & $5.00 \mathrm{~b}-\mathrm{d}$ & -13.04 \\
\hline 12 & $61.85 \mathrm{ab}$ & $60.33 a$ & -2.45 & $50.22 \mathrm{a}$ & -18.80 & $25.71 \mathrm{a}-\mathrm{d}$ & $32.44 \mathrm{a}$ & 26.17 & $28.22 \mathrm{~b}-\mathrm{d}$ & 9.76 & $7.57 \mathrm{a}-\mathrm{d}$ & $8.33 \mathrm{a}$ & 10.03 & $5.67 \mathrm{a}-\mathrm{c}$ & -25.09 \\
\hline 13 & $54.62 \mathrm{bc}$ & $57.00 \mathrm{ab}$ & 4.35 & $39.71 a$ & -27.29 & $32.00 \mathrm{a}$ & $27.00 \mathrm{a}$ & -15.62 & $32.42 \mathrm{a}-\mathrm{c}$ & 1.31 & $6.88 \mathrm{~b}-\mathrm{d}$ & $8.00 \mathrm{ab}$ & 16.27 & $5.86 \mathrm{ab}$ & -14.82 \\
\hline 14 & $54.33 b c$ & $27.66 \mathrm{e}$ & -49.08 & $16.55 \mathrm{~d}-\mathrm{g}$ & -69.53 & $31.55 \mathrm{ab}$ & $34.00 \mathrm{a}$ & 7.76 & $35.77 \mathrm{a}$ & 13.37 & $8.33 \mathrm{a}-\mathrm{c}$ & 7.00 a-e & -15.96 & $5.33 \mathrm{~b}-\mathrm{d}$ & -36.01 \\
\hline 15 & $59.22 \mathrm{a}-\mathrm{c}$ & $51.75 \mathrm{a}-\mathrm{c}$ & -12.61 & 34.33ab & -42.02 & $26.66 \mathrm{a}-\mathrm{c}$ & $29.87 \mathrm{a}$ & 12.04 & $27.77 b-d$ & 4.16 & 7.67 a-d & $8.00 \mathrm{ab}$ & 4.30 & $5.44 \mathrm{a}-\mathrm{d}$ & -29.07 \\
\hline 16 & $47.66 \mathrm{bc}$ & $23.00 \mathrm{ef}$ & -51.74 & $20.55 c-f$ & -56.88 & $29.11 \mathrm{a}-\mathrm{c}$ & $30.88 \mathrm{a}$ & 6.08 & $25.55 \mathrm{~cd}$ & -12.22 & $7.00 \mathrm{~b}-\mathrm{d}$ & $5.00 \mathrm{f}$ & -28.57 & $5.33 \mathrm{~b}-\mathrm{d}$ & -23.85 \\
\hline 17 & $58.50 \mathrm{a}-\mathrm{c}$ & $45.66 \mathrm{bc}$ & -21.94 & $41.66 \mathrm{a}$ & -28.78 & $29.66 \mathrm{a}-\mathrm{c}$ & $29.77 \mathrm{a}$ & 0.37 & $30.83 \mathrm{a}-\mathrm{d}$ & 3.94 & $5.50 \mathrm{~d}$ & $5.00 \mathrm{f}$ & -9.09 & $5.00 \mathrm{~b}-\mathrm{d}$ & -9.09 \\
\hline 18 & $17.33 \mathrm{~d}$ & $13.88 \mathrm{fg}$ & -19.90 & $8.55 \mathrm{~g}$ & -50.66 & $26.22 \mathrm{a}-\mathrm{d}$ & $27.88 \mathrm{a}$ & 6.33 & $28.00 \mathrm{~b}-\mathrm{d}$ & 6.78 & $7.33 \mathrm{a}-\mathrm{d}$ & $6.33 \mathrm{c}-\mathrm{f}$ & -13.64 & $5.00 \mathrm{~b}-\mathrm{d}$ & -31.78 \\
\hline 19 & $55.00 \mathrm{bc}$ & $50.00 \mathrm{a}-\mathrm{c}$ & -9.090 & $25.00 \mathrm{~b}-\mathrm{e}$ & -54.54 & $30.00 \mathrm{a}-\mathrm{c}$ & $31.33 \mathrm{a}$ & 4.43 & $24.33 \mathrm{~d}$ & -18.9 & $9.00 \mathrm{ab}$ & $7.33 \mathrm{a}-\mathrm{d}$ & -18.55 & $4.00 \mathrm{de}$ & -55.55 \\
\hline 20 & $45.55 \mathrm{c}$ & $25.55 \mathrm{e}$ & -43.90 & $15.33 \mathrm{e}-\mathrm{g}$ & -66.34 & $25.44 \mathrm{a}-\mathrm{d}$ & $30.00 \mathrm{a}$ & 17.92 & $29.11 \mathrm{a}-\mathrm{d}$ & 14.42 & $8.33 \mathrm{a}-\mathrm{c}$ & $7.33 \mathrm{a}-\mathrm{d}$ & -12.00 & $4.67 \mathrm{~b}-\mathrm{d}$ & -43.93 \\
\hline Ort. & $46.01 \mathrm{~A}$ & $35.82 \mathrm{~B}$ & -22.14 & $28.43 \mathrm{C}$ & -38.20 & $26.65 \mathrm{~B}$ & $30.05 \mathrm{~A}$ & 12.75 & $29.17 \mathrm{~A}$ & 9.45 & 7.09A & $6.72 \mathrm{~B}$ & -5.21 & $5.09 \mathrm{C}$ & -28.20 \\
\hline
\end{tabular}

*Her bir sütunda farklı harflerle gösterilen uygulamalar arasında istatistiksel olarak fark varken ( $<<0.05)$, aynı harfle gösterilen uygulamalar arasında bir faklılık yoktur ( $<0.05$ ) 
Çizelge 4. Farklı tuz dozları sonunda genotiplerde sürgün yaş ağırlığı, sürgün kuru ağırlı̆̆ı, sürgün çapı ve kontrole göre değişimleri (\%)

\begin{tabular}{|c|c|c|c|c|c|c|c|c|c|c|c|c|c|c|c|}
\hline \multicolumn{6}{|c|}{ Sürgün yaş ăğırlı̆̆ı (g) } & \multicolumn{5}{|c|}{ Sürgün kuru ăğırlığı (g) } & \multicolumn{5}{|c|}{ Sürgün çapı (mm) } \\
\hline Genotip & Kontrol & $25 \mathrm{mM}$ & $25 \mathrm{mM} \%$ & $50 \mathrm{mM}$ & $50 \mathrm{mM} \%$ & Kontrol & $25 \mathrm{mM}$ & $25 \mathrm{mM} \%$ & $50 \mathrm{mM}$ & $50 \mathrm{mM} \%$ & Kontrol & $25 \mathrm{mM}$ & $25 \mathrm{mM} \%$ & $50 \mathrm{mM}$ & $50 \mathrm{mM} \%$ \\
\hline 1 & $11.90 \mathrm{~d}-\mathrm{f}$ & $8.64 \mathrm{de}$ & -27.39 & $5.86 \mathrm{e}-\mathrm{g}$ & $\begin{array}{l}-50.75 \\
\end{array}$ & $0.73 \mathrm{de}$ & $0.54 \mathrm{~d}$ & -26.02 & $0.80 \mathrm{~d}-\mathrm{f}$ & 9.58 & $2.64 \mathrm{~g}$ & $2.57 \mathrm{ef}$ & -2.65 & $2.39 \mathrm{de}$ & -9.47 \\
\hline 2 & $16.34 b-f$ & $17.49 \mathrm{a}-\mathrm{c}$ & 7.03 & $5.69 \mathrm{e}-\mathrm{g}$ & -65.17 & $0.96 \mathrm{~b}-\mathrm{e}$ & $1.31 \mathrm{a}-\mathrm{c}$ & 36.45 & $1.08 \mathrm{~b}-\mathrm{f}$ & 12.50 & $4.05 \mathrm{~b}$ & $3.49 \mathrm{a}-\mathrm{c}$ & -13.82 & $2.81 \mathrm{~b}-\mathrm{d}$ & -30.61 \\
\hline 3 & 17.76 a-e & $15.65 \mathrm{a}-\mathrm{c}$ & -11.88 & $6.90 \mathrm{~d}-\mathrm{g}$ & -61.14 & $1.10 \mathrm{a}-\mathrm{e}$ & $1.25 \mathrm{a}-\mathrm{c}$ & 13.63 & $1.27 \mathrm{a}-\mathrm{e}$ & 15.45 & $3.28 \mathrm{ef}$ & 2.96de & -9.75 & $2.97 \mathrm{~b}-\mathrm{d}$ & -9.45 \\
\hline 4 & $13.46 \mathrm{c}-\mathrm{f}$ & $14.58 \mathrm{a}-\mathrm{d}$ & 8.32 & $8.88 \mathrm{~b}-\mathrm{g}$ & -34.02 & $0.82 \mathrm{c}-\mathrm{e}$ & $1.19 \mathrm{a}-\mathrm{c}$ & 45.12 & $1.20 \mathrm{a}-\mathrm{f}$ & 46.34 & $2.86 \mathrm{fg}$ & $3.02 \mathrm{~d}$ & 5.59 & $2.77 \mathrm{~b}-\mathrm{d}$ & -3.14 \\
\hline 5 & $25.36 \mathrm{a}$ & $19.87 \mathrm{a}$ & -21.64 & $11.71 \mathrm{a}-\mathrm{e}$ & -53.82 & $1.78 \mathrm{a}$ & $1.67 \mathrm{a}$ & -6.17 & $1.30 \mathrm{a}-\mathrm{e}$ & -26.96 & $4.73 a$ & $3.92 \mathrm{a}$ & -17.12 & $3.36 \mathrm{ab}$ & -28.96 \\
\hline 6 & $17.33 \mathrm{a}-\mathrm{f}$ & $15.86 \mathrm{a}-\mathrm{c}$ & -8.55 & $9.61 \mathrm{a}-\mathrm{f}$ & -44.54 & $1.08 \mathrm{a}-\mathrm{e}$ & $1.27 \mathrm{a}-\mathrm{c}$ & 17.59 & $1.10 \mathrm{~b}-\mathrm{f}$ & 1.85 & $3.43 \mathrm{c}-\mathrm{e}$ & $3.10 \mathrm{~cd}$ & -9.62 & $2.88 \mathrm{~b}-\mathrm{d}$ & -16.03 \\
\hline 7 & $13.71 \mathrm{c}-\mathrm{f}$ & $15.16 \mathrm{a}-\mathrm{c}$ & 10.57 & $6.76 \mathrm{~d}-\mathrm{g}$ & -50.69 & $0.86 \mathrm{c}-\mathrm{e}$ & $1.31 \mathrm{a}-\mathrm{c}$ & 52.32 & $1.50 \mathrm{a}-\mathrm{e}$ & 74.41 & $3.23 \mathrm{ef}$ & $3.14 \mathrm{~cd}$ & -2.78 & $2.91 \mathrm{~b}-\mathrm{d}$ & -9.90 \\
\hline 8 & $16.72 \mathrm{~b}-\mathrm{f}$ & $17.27 \mathrm{a}-\mathrm{c}$ & 3.28 & $16.42 \mathrm{a}$ & -1.79 & $1.10 \mathrm{a}-\mathrm{e}$ & $1.45 \mathrm{ab}$ & 31.81 & $1.47 \mathrm{a}-\mathrm{e}$ & 33.63 & $3.27 \mathrm{ef}$ & $3.26 \mathrm{~b}-\mathrm{d}$ & -0.30 & $3.05 \mathrm{a}-\mathrm{c}$ & -6.72 \\
\hline 9 & $9.29 \mathrm{f}$ & $7.81 \mathrm{e}$ & -15.93 & $8.03 \mathrm{c}-\mathrm{g}$ & -13.56 & $0.45 \mathrm{e}$ & $0.49 \mathrm{~d}$ & 8.88 & $0.51 \mathrm{f}$ & 13.33 & $3.28 \mathrm{ef}$ & $3.07 \mathrm{~cd}$ & -6.40 & 2.44de & -25.61 \\
\hline 10 & $20.44 \mathrm{a}-\mathrm{c}$ & $17.55 \mathrm{a}-\mathrm{c}$ & -14.13 & $15.58 \mathrm{a}$ & -23.77 & $1.60 \mathrm{ab}$ & $1.65 \mathrm{a}$ & 3.12 & $1.47 \mathrm{a}-\mathrm{e}$ & -8.12 & $3.56 \mathrm{c}-\mathrm{e}$ & $3.52 \mathrm{a}-\mathrm{c}$ & -1.12 & $3.13 \mathrm{a}-\mathrm{c}$ & -12.07 \\
\hline 11 & $9.64 \mathrm{ef}$ & $11.67 \mathrm{c}-\mathrm{e}$ & 21.05 & $5.58 \mathrm{e}-\mathrm{g}$ & -42.11 & $0.45 \mathrm{e}$ & $0.69 \mathrm{~cd}$ & 53.33 & $0.83 \mathrm{~d}-\mathrm{f}$ & 84.44 & $2.46 \mathrm{~g}$ & $2.45 \mathrm{f}$ & -0.40 & $1.89 \mathrm{e}$ & -23.17 \\
\hline 12 & $15.08 \mathrm{~b}-\mathrm{f}$ & $18.34 \mathrm{ab}$ & 21.61 & $12.80 \mathrm{a}-\mathrm{d}$ & -15.11 & $0.97 \mathrm{~b}-\mathrm{e}$ & $1.54 \mathrm{ab}$ & 58.76 & $1.65 \mathrm{a}-\mathrm{c}$ & 70.10 & $3.39 \mathrm{c}-\mathrm{e}$ & $3.07 \mathrm{~cd}$ & -9.44 & $2.81 \mathrm{~b}-\mathrm{d}$ & -17.10 \\
\hline 13 & $19.58 \mathrm{a}-\mathrm{d}$ & $12.77 \mathrm{~b}-\mathrm{e}$ & -34.78 & 10.98 a-e & -43.92 & $1.48 \mathrm{a}-\mathrm{c}$ & $1.61 \mathrm{a}$ & 8.78 & $1.73 \mathrm{ab}$ & 16.89 & 3.77 b-d & $3.53 \mathrm{a}-\mathrm{c}$ & -6.36 & $3.60 \mathrm{a}$ & -4.50 \\
\hline 14 & $16.46 \mathrm{~b}-\mathrm{f}$ & $13.00 \mathrm{~b}-\mathrm{e}$ & -21.02 & $7.19 \mathrm{~d}-\mathrm{g}$ & -56.31 & $0.67 \mathrm{de}$ & $0.93 \mathrm{~b}-\mathrm{d}$ & 38.80 & $1.27 \mathrm{a}-\mathrm{e}$ & 89.55 & $3.20 \mathrm{ef}$ & 2.94de & -8.12 & $2.16 \mathrm{e}$ & -32.50 \\
\hline 15 & 22.13ab & $17.71 \mathrm{a}-\mathrm{c}$ & -19.97 & 15.12ab & -31.67 & 1.60ab & $1.62 \mathrm{a}$ & 1.25 & $1.86 \mathrm{a}$ & 16.25 & $3.80 \mathrm{bc}$ & 3.69ab & -2.89 & $3.19 \mathrm{a}-\mathrm{c}$ & -16.05 \\
\hline 16 & $17.29 \mathrm{a}-\mathrm{f}$ & $15.33 \mathrm{a}-\mathrm{c}$ & -11.33 & $13.87 \mathrm{a}-\mathrm{c}$ & -19.78 & $1.19 \mathrm{a}-\mathrm{d}$ & $1.38 \mathrm{ab}$ & 15.96 & $1.55 \mathrm{a}-\mathrm{d}$ & 30.25 & $3.31 \mathrm{~d}-\mathrm{f}$ & $3.12 \mathrm{~cd}$ & -5.74 & $2.95 \mathrm{~b}-\mathrm{d}$ & -10.87 \\
\hline 17 & $12.07 \mathrm{~d}-\mathrm{f}$ & $13.44 \mathrm{a}-\mathrm{e}$ & 11.35 & $4.27 \mathrm{fg}$ & -64.62 & $0.85 \mathrm{c}-\mathrm{e}$ & $1.02 \mathrm{a}-\mathrm{d}$ & 20.00 & $0.90 \mathrm{c}-\mathrm{f}$ & 5.88 & $3.54 \mathrm{c}-\mathrm{e}$ & $3.68 \mathrm{ab}$ & 3.95 & $2.89 \mathrm{~b}-\mathrm{d}$ & -18.36 \\
\hline 18 & $11.25 \mathrm{~d}-\mathrm{f}$ & 8.38de & -25.51 & $2.90 \mathrm{~g}$ & -74.22 & $0.67 \mathrm{de}$ & $0.55 \mathrm{~d}$ & -17.91 & $0.76 \mathrm{ef}$ & 13.43 & $2.74 \mathrm{~g}$ & $2.23 \mathrm{f}$ & -18.61 & $2.00 \mathrm{e}$ & -27.00 \\
\hline 19 & $13.20 \mathrm{c}-\mathrm{f}$ & $16.72 \mathrm{a}-\mathrm{c}$ & 26.66 & $7.37 \mathrm{~d}-\mathrm{g}$ & -44.16 & 0.91 b-e & $1.41 \mathrm{ab}$ & 54.94 & $0.75 \mathrm{ef}$ & -17.58 & 3.62 b-e & $3.38 \mathrm{~b}-\mathrm{d}$ & -6.63 & $3.15 \mathrm{a}-\mathrm{c}$ & -12.98 \\
\hline 20 & $21.10 \mathrm{a}-\mathrm{c}$ & $17.65 \mathrm{a}-\mathrm{c}$ & -16.35 & $8.93 \mathrm{~b}-\mathrm{g}$ & -57.67 & $1.32 \mathrm{a}-\mathrm{d}$ & $1.25 \mathrm{a}-\mathrm{c}$ & -5.30 & $1.35 \mathrm{a}-\mathrm{e}$ & 2.27 & 3.77 b-d & $3.50 \mathrm{a}-\mathrm{c}$ & -7.16 & $2.73 \mathrm{~cd}$ & -27.58 \\
\hline Ort. & $16.00 \mathrm{~A}$ & $14.74 \mathrm{~A}$ & -8.12 & $9.28 \mathrm{~B}$ & -42.00 & $1.03 \mathrm{~B}$ & $1.20 \mathrm{~A}$ & 16.50 & $1.22 \mathrm{~A}$ & 18.44 & $3.38 \mathrm{~A}$ & $3.17 \mathrm{~B}$ & -6.21 & $2.78 \mathrm{C}$ & -17.75 \\
\hline
\end{tabular}

*Her bir sütunda farklı harflerle gösterilen uygulamalar arasında istatistiksel olarak fark varken ( $<<0.05)$, aynı harfle gösterilen uygulamalar arasında bir faklılık yoktur ( $<0.05$ ) 
Çizelge 5. Farklı tuz dozları sonunda genotiplerde sürgün $\mathrm{Na}, \mathrm{Ca}, \mathrm{K}$ konsantrasyonları (ppm) ve kontrole göre değişimleri (\%)

\begin{tabular}{|c|c|c|c|c|c|c|c|c|c|c|c|c|c|c|c|}
\hline \multicolumn{6}{|c|}{$\mathrm{Na}$} & \multicolumn{6}{|c|}{$C a$} & \multicolumn{3}{|c|}{$K$} & \multirow[b]{2}{*}{$\begin{array}{ll}50 & \mathrm{mM} \\
\% & \\
\end{array}$} \\
\hline Genotip & Kontrol & $25 \mathrm{mM}$ & $\begin{array}{l}25 \mathrm{mM} \\
\%\end{array}$ & $50 \mathrm{mM}$ & $\begin{array}{ll}50 & \mathrm{mM} \\
\% & \\
\end{array}$ & Kontrol & $25 \mathrm{mM}$ & $\begin{array}{ll}25 & \mathrm{mM} \\
\% & \\
\end{array}$ & $50 \mathrm{mM}$ & $\begin{array}{ll}50 & \mathrm{mM} \\
\% & \\
\end{array}$ & Kontrol & $25 \mathrm{mM}$ & $\begin{array}{ll}25 & \mathrm{mM} \\
\% & \\
\end{array}$ & $50 \mathrm{mM}$ & \\
\hline 1 & $3384.04 a$ & $11326.69 a$ & 234.70 & $30793.69 a$ & 809.96 & $3827.47 \mathrm{a}$ & $5140.04 a$ & 34.29 & $4969.57 a$ & 29.83 & $42160.73 a$ & $36925.64 a$ & -12.41 & $33222.69 a$ & -21.19 \\
\hline 2 & $2030.65 \mathrm{a}$ & $4255.97 \mathrm{a}$ & 109.58 & $29442.05 a$ & 1349.88 & $3135.02 \mathrm{a}$ & $3870.27 a$ & 23.45 & $5739.65 a$ & 83.08 & $42571.42 \mathrm{a}$ & $39485.95 a$ & -7.24 & $32302.47 \mathrm{a}$ & -24.12 \\
\hline 3 & 2190.86a & $6638.72 \mathrm{a}$ & 203.01 & $30076.52 \mathrm{a}$ & 1272.82 & $3381.53 \mathrm{a}$ & $3479.75 a$ & 2.90 & $5073.23 \mathrm{a}$ & 50.02 & $43906.34 a$ & $34740.43 a$ & -20.87 & $30799.18 \mathrm{a}$ & -29.85 \\
\hline 4 & $3855.07 \mathrm{a}$ & $3847.16 a$ & -0.20 & $29430.25 a$ & 663.41 & $2825.38 \mathrm{a}$ & $3807.09 \mathrm{a}$ & 34.74 & $4586.87 \mathrm{a}$ & 62.34 & $44377.30 \mathrm{a}$ & $35206.53 a$ & -20.66 & $30935.27 \mathrm{a}$ & -30.29 \\
\hline 5 & $3455.85 \mathrm{a}$ & $5361.74 \mathrm{a}$ & 55.14 & $29250.34 a$ & 746.40 & $2645.37 \mathrm{a}$ & $3025.90 \mathrm{a}$ & 14.38 & $5297.73 \mathrm{a}$ & 100.26 & $36825.57 \mathrm{a}$ & $33923.20 \mathrm{a}$ & -7.88 & $30463.34 a$ & -17.27 \\
\hline 6 & $2227.34 \mathrm{a}$ & $5147.09 \mathrm{a}$ & 131.08 & $31936.78 \mathrm{a}$ & 1333.85 & $3282.99 \mathrm{a}$ & $3289.95 \mathrm{a}$ & 0.21 & $4677.88 \mathrm{a}$ & 42.48 & 42130.01a & $34948.46 a$ & -17.04 & $31265.93 a$ & -25.78 \\
\hline 7 & $2338.55 \mathrm{a}$ & $5701.33 \mathrm{a}$ & 143.79 & $31537.56 a$ & 1248.59 & $2767.73 a$ & $3156.94 a$ & 14.06 & $4748.04 a$ & 71.55 & $42651.84 \mathrm{a}$ & $32130.34 a$ & -24.66 & 26958.76a & -36.79 \\
\hline 8 & $3006.86 \mathrm{a}$ & $9798.51 \mathrm{a}$ & 225.87 & $27520.09 \mathrm{a}$ & 815.24 & $2782.48 \mathrm{a}$ & $4630.09 \mathrm{a}$ & 66.40 & $4372.16 \mathrm{a}$ & 57.13 & $37060.31 \mathrm{a}$ & $35131.62 \mathrm{a}$ & -5.20 & $27759.92 \mathrm{a}$ & -25.09 \\
\hline 9 & $3318.07 \mathrm{a}$ & $8536.30 \mathrm{a}$ & 157.26 & $31625.18 \mathrm{a}$ & 853.12 & $3527.33 \mathrm{a}$ & $3468.24 a$ & -1.67 & $3961.91 \mathrm{a}$ & 12.32 & $39703.97 a$ & $33465.26 a$ & -15.71 & $27202.96 a$ & -31.48 \\
\hline 10 & $2268.30 \mathrm{a}$ & $5385.84 \mathrm{a}$ & 137.43 & $25463.33 \mathrm{a}$ & 1022.57 & $2581.09 \mathrm{a}$ & $3248.88 \mathrm{a}$ & 25.87 & $4206.56 a$ & 62.97 & $29387.13 \mathrm{a}$ & $31903.12 \mathrm{a}$ & 8.56 & $28161.09 \mathrm{a}$ & -4.17 \\
\hline 11 & $4109.25 \mathrm{a}$ & $8291.33 a$ & 101.77 & $31310.08 \mathrm{a}$ & 661.94 & $3339.69 a$ & $3706.63 a$ & 10.98 & $4462.29 \mathrm{a}$ & 33.61 & 36409.31a & $38392.38 \mathrm{a}$ & 5.44 & $30757.70 \mathrm{a}$ & -15.52 \\
\hline 12 & $2329.49 \mathrm{a}$ & $5487.72 \mathrm{a}$ & 135.57 & $26981.14 \mathrm{a}$ & 1058.24 & $3056.26 \mathrm{a}$ & $3502.60 \mathrm{a}$ & 14.60 & $5375.22 \mathrm{a}$ & 75.87 & $36033.10 \mathrm{a}$ & $30747.98 \mathrm{a}$ & -14.66 & $28365.36 \mathrm{a}$ & -21.27 \\
\hline 13 & $7045.84 a$ & $7410.00 \mathrm{a}$ & 5.16 & $28153.27 \mathrm{a}$ & 299.57 & $3495.55 a$ & $3160.62 a$ & -9.58 & $6048.92 \mathrm{a}$ & 73.04 & $35635.17 \mathrm{a}$ & $34132.59 a$ & -4.21 & $27670.36 a$ & -22.35 \\
\hline 14 & $1893.84 \mathrm{a}$ & $11196.56 \mathrm{a}$ & 491.20 & $31514.49 a$ & 1564.05 & $3402.81 \mathrm{a}$ & $4722.51 \mathrm{a}$ & 38.78 & $4946.16 a$ & 45.35 & $38667.82 \mathrm{a}$ & $33661.76 a$ & -12.94 & $28630.30 \mathrm{a}$ & -25.95 \\
\hline 15 & $3084.76 a$ & $5556.55 \mathrm{a}$ & 80.12 & $24486.80 \mathrm{a}$ & 693.80 & $2907.55 a$ & $3272.25 \mathrm{a}$ & 12.54 & $4100.93 a$ & 41.04 & $38581.75 a$ & $36021.43 \mathrm{a}$ & -6.63 & $26634.07 \mathrm{a}$ & -30.96 \\
\hline 16 & $3458.44 a$ & $5225.12 \mathrm{a}$ & 51.08 & $29255.53 a$ & 745.91 & $3379.95 a$ & $3154.65 \mathrm{a}$ & -6.66 & $4443.24 \mathrm{a}$ & 31.45 & $37691.29 a$ & $33490.28 \mathrm{a}$ & -11.14 & $27757.46 a$ & -26.35 \\
\hline 17 & $3570.30 \mathrm{a}$ & $6057.91 \mathrm{a}$ & 69.67 & $29537.84 a$ & 727.32 & $2727.24 \mathrm{a}$ & $3135.35 a$ & 14.96 & $4741.08 \mathrm{a}$ & 73.84 & $39853.55 \mathrm{a}$ & $37719.41 \mathrm{a}$ & -5.35 & $30852.84 \mathrm{a}$ & -22.58 \\
\hline 18 & $3214.12 \mathrm{a}$ & $11050.48 \mathrm{a}$ & 243.81 & $31861.86 a$ & 891.31 & $3502.99 \mathrm{a}$ & $3784.73 a$ & 8.04 & $4693.51 \mathrm{a}$ & 33.98 & 42719.11a & $35565.44 a$ & -16.74 & $30741.37 \mathrm{a}$ & -28.03 \\
\hline 19 & $3312.63 \mathrm{a}$ & $4686.69 a$ & 41.47 & $27372.01 \mathrm{a}$ & 726.29 & $2761.98 \mathrm{a}$ & $3124.65 a$ & 13.13 & $3468.40 \mathrm{a}$ & 25.57 & $35796.03 \mathrm{a}$ & $33786.97 \mathrm{a}$ & -5.61 & 27404.71a & -23.44 \\
\hline 20 & $3359.55 \mathrm{a}$ & $5455.84 \mathrm{a}$ & 62.39 & $32966.20 \mathrm{a}$ & 881.26 & $2995.76 a$ & $3408.90 \mathrm{a}$ & 13.79 & $4583.72 \mathrm{a}$ & 53.00 & $42455.73 \mathrm{a}$ & $38772.93 \mathrm{a}$ & -8.67 & $32466.70 \mathrm{a}$ & -23.52 \\
\hline Ort. & $3208.95 \mathrm{C}$ & 6810.89B & 112.24 & $29542.76 \mathrm{~A}$ & 820.63 & $3108.32 \mathrm{C}$ & $3612.03 \mathrm{~B}$ & 16.20 & $4724.80 \mathrm{~A}$ & 52.00 & $39195.22 \mathrm{~A}$ & $35022.42 \mathrm{~B}$ & -10.64 & $29440.83 \mathrm{C}$ & -24.88 \\
\hline
\end{tabular}

*Her bir sütunda farklı harflerle gösterilen uygulamalar arasında istatistiksel olarak fark varken $(\mathrm{p}<0.05)$, aynı harfle gösterilen uygulamalar arasında bir faklı11k yoktur $(\mathrm{p}<0.05)$ 
Yetişir ve Uygur (2009), kabak genotiplerinde yaptıkları çalışmada, $\mathrm{Na}$ konsantrasyonundaki artışın, Ca/ $\mathrm{Na}$ ve $\mathrm{K} / \mathrm{Na}$ oranlarında azalmaya neden olduğunu bildirmişlerdir. Daşgan ve ark. (2002), Na artışı ile K/Na ve Ca/ $\mathrm{Na}$ oranlarının azaldığını belirtirken, bu oranlar ile skala arasında önemli bir bağlantı olduğunu, K/Na ve Ca/ $/ \mathrm{Na}$ oranlarının yüksek olduğu genotiplerde, daha düşük skala değerlerinin oluştuğunu saptamışlardır. Kuşvuran (2012), kavunda yaptığı tuzluluk çalışmasında, genotiplerin K/Na değerlerinde, tuz stresinin neden olduğu önemli oranda azalmaları saptamıştır. Na iyonunun tuz ortamında bünyede artması ile birlikte genotiplerin genel olarak K iyon konsantrasyonunun azalması $\mathrm{K} / \mathrm{Na}$ oranlarının da azalmasına neden olmuştur. Yapılan çalışmalar elde ettiğimiz sonuçlarla büyük oranda benzerlikler göstermiş olup, $\mathrm{K} / \mathrm{Na}$ değerleri içerisinde her iki doz uygulamasında tüm genotiplerde azalmalar olurken, $25 \mathrm{Mm}$ dozuna maruz bırakılan 4 no'lu genotipin $\mathrm{Ca} / \mathrm{Na}$ değerlerinde artış gösterdiği dikkat çekmiştir. Kuşvuran ve ark. (2007), kavunda tuz stresi zararının $\mathrm{Na}$ ve $\mathrm{Cl}$ iyonlarının toksik etkisinden kaynaklandığını, bu iyonları bünyelerinde az bulunduran genotiplerin tuza toleransının daha yüksek olduğu belirlenmiştir. Araştırmacıların belirttiklerine uyumlu olarak, 4 no'lu genotipin $25 \mathrm{Mm}$ tuz dozunda $\mathrm{Na}$ bünyesinde az miktarda biriktirdiği ve olumsuz etkilenmediği tespit edilmiştir. $\mathrm{Ca} / \mathrm{Na}$ oranında $50 \mathrm{Mm}$ tuz stresine maruz tüm genotiplerde ise azalmalar meydana gelmiştir. $25 \mathrm{mM}$ tuz uygulamasının kontrol grubu \% değişim oranlarına göre sürgünlerdeki K/Na konsantrasyonundan en fazla etkilenen \% $\mathbf{- 7 7 . 9 5}$ ile 9 no'lu genotip olurken en az etkilenen ise \% -32.46 ile 4 no'lu genotip; $50 \mathrm{mM}$ tuz uygulamasinda en fazla etkilenen \% -95.59 ile 14 no'lu genotip iken en az etkilenen ise $\%-88.16$ ile 13 no'lu genotip olmuştur. Ca/ $\mathrm{Na}$ oranında $25 \mathrm{Mm}$ dozunda en fazla azalma \% -72.54 ile 9 no'lu genotipten, en az ise \% -11.53 ile 8 no'lu genotipten; $50 \mathrm{Mm}$ tuz dozunda en fazla azalma \% -91.50 ile 9 no'lu genotipten en az ise \% -67.60 ile 13 no'lu genotipten elde edilmiştir (Çizelge 6).

Çizelge 6. Farklı tuz dozları sonunda genotiplerde sürgün $\mathrm{K} / \mathrm{Na}, \mathrm{Ca} / \mathrm{Na}$ konsantrasyonları (ppm) ve kontrole göre değişimleri $(\%)$

\begin{tabular}{lllllllllll}
\hline \multicolumn{9}{c}{$K / N \boldsymbol{a}$} & \multicolumn{5}{c}{$\boldsymbol{C a} / \boldsymbol{N a}$} \\
\hline & & 25 & $25 \mathrm{mM}$ & 50 & $50 \mathrm{mM}$ & \multirow{2}{*}{ Kontrol } & 25 & $25 \mathrm{mM}$ & 50 & $50 \mathrm{mM}$ \\
Genotip & Kontrol & $\mathrm{mM}$ & $\%$ & $\mathrm{mM}$ & $\%$ & & $\%$ & $\mathrm{mM}$ & $\%$ \\
\hline 1 & $15.48 \mathrm{a}$ & $4.55 \mathrm{a}$ & -70.60 & $1.09 \mathrm{a}$ & -92.95 & $1.35 \mathrm{a}$ & $0.57 \mathrm{a}$ & -57.77 & $0.16 \mathrm{a}$ & -88.14 \\
2 & $21.04 \mathrm{a}$ & $9.32 \mathrm{a}$ & -55.70 & $1.12 \mathrm{a}$ & -94.67 & $1.56 \mathrm{a}$ & $0.90 \mathrm{a}$ & -42.30 & $0.20 \mathrm{a}$ & -87.17 \\
3 & $20.05 \mathrm{a}$ & $6.25 \mathrm{a}$ & -68.82 & $1.02 \mathrm{a}$ & -94.91 & $1.55 \mathrm{a}$ & $0.65 \mathrm{a}$ & -58.06 & $0.17 \mathrm{a}$ & -89.03 \\
4 & $13.77 \mathrm{a}$ & $9.30 \mathrm{a}$ & -32.46 & $1.06 \mathrm{a}$ & -92.30 & $0.82 \mathrm{a}$ & $1.00 \mathrm{a}$ & 21.95 & $0.15 \mathrm{a}$ & -81.70 \\
5 & $12.46 \mathrm{a}$ & $6.59 \mathrm{a}$ & -47.11 & $1.06 \mathrm{a}$ & -91.49 & $0.89 \mathrm{a}$ & $0.61 \mathrm{a}$ & -31.46 & $0.20 \mathrm{a}$ & -77.52 \\
6 & $19.12 \mathrm{a}$ & $7.86 \mathrm{a}$ & -58.89 & $0.98 \mathrm{a}$ & -94.87 & $1.48 \mathrm{a}$ & $0.76 \mathrm{a}$ & -48.64 & $0.14 \mathrm{a}$ & -90.54 \\
7 & $18.24 \mathrm{a}$ & $5.89 \mathrm{a}$ & -67.70 & $0.85 \mathrm{a}$ & -95.33 & $1.18 \mathrm{a}$ & $0.58 \mathrm{a}$ & -50.84 & $0.15 \mathrm{a}$ & -87.28 \\
8 & $14.92 \mathrm{a}$ & $8.34 \mathrm{a}$ & -44.10 & $1.01 \mathrm{a}$ & -93.23 & $1.04 \mathrm{a}$ & $0.92 \mathrm{a}$ & -11.53 & $0.16 \mathrm{a}$ & -84.61 \\
9 & $18.69 \mathrm{a}$ & $4.12 \mathrm{a}$ & -77.95 & $0.86 \mathrm{a}$ & -95.39 & $1.53 \mathrm{a}$ & $0.42 \mathrm{a}$ & -72.54 & $0.13 \mathrm{a}$ & -91.50 \\
10 & $13.04 \mathrm{a}$ & $6.37 \mathrm{a}$ & -51.15 & $1.11 \mathrm{a}$ & -91.48 & $1.14 \mathrm{a}$ & $0.67 \mathrm{a}$ & -41.22 & $0.17 \mathrm{a}$ & -85.08 \\
11 & $10.85 \mathrm{a}$ & $5.59 \mathrm{a}$ & -48.47 & $0.98 \mathrm{a}$ & -90.96 & $0.96 \mathrm{a}$ & $0.51 \mathrm{a}$ & -46.87 & $0.14 \mathrm{a}$ & -85.41 \\
12 & $15.42 \mathrm{a}$ & $5.66 \mathrm{a}$ & -63.29 & $1.06 \mathrm{a}$ & -93.12 & $1.32 \mathrm{a}$ & $0.65 \mathrm{a}$ & -50.75 & $0.21 \mathrm{a}$ & -84.09 \\
13 & $8.45 \mathrm{a}$ & $4.59 \mathrm{a}$ & -45.68 & $1.00 \mathrm{a}$ & -88.16 & $0.71 \mathrm{a}$ & $0.44 \mathrm{a}$ & -38.02 & $0.23 \mathrm{a}$ & -67.60 \\
14 & $20.64 \mathrm{a}$ & $5.29 \mathrm{a}$ & -74.37 & $0.91 \mathrm{a}$ & -95.59 & $1.85 \mathrm{a}$ & $0.60 \mathrm{a}$ & -67.56 & $0.16 \mathrm{a}$ & -91.35 \\
15 & $15.15 \mathrm{a}$ & $7.53 \mathrm{a}$ & -50.29 & $1.16 \mathrm{a}$ & -92.34 & $1.10 \mathrm{a}$ & $0.68 \mathrm{a}$ & -38.18 & $0.18 \mathrm{a}$ & -83.63 \\
16 & $12.49 \mathrm{a}$ & $7.53 \mathrm{a}$ & -39.71 & $0.95 \mathrm{a}$ & -92.39 & $1.08 \mathrm{a}$ & $0.71 \mathrm{a}$ & -34.25 & $0.15 \mathrm{a}$ & -86.11 \\
17 & $13.16 \mathrm{a}$ & $6.29 \mathrm{a}$ & -52.20 & $1.04 \mathrm{a}$ & -92.09 & $0.88 \mathrm{a}$ & $0.53 \mathrm{a}$ & -39.77 & $0.16 \mathrm{a}$ & -81.81 \\
18 & $14.94 \mathrm{a}$ & $3.75 \mathrm{a}$ & -74.89 & $0.97 \mathrm{a}$ & -93.50 & $1.20 \mathrm{a}$ & $0.39 \mathrm{a}$ & -67.50 & $0.15 \mathrm{a}$ & -87.78 \\
19 & $13.31 \mathrm{a}$ & $7.50 \mathrm{a}$ & -43.65 & $1.04 \mathrm{a}$ & -92.18 & $1.01 \mathrm{a}$ & $0.72 \mathrm{a}$ & -28.71 & $0.13 \mathrm{a}$ & -87.12 \\
20 & $15.88 \mathrm{a}$ & $7.47 \mathrm{a}$ & -52.95 & $0.99 \mathrm{a}$ & -93.76 & $1.04 \mathrm{a}$ & $0.64 \mathrm{a}$ & -38.46 & $0.14 \mathrm{a}$ & -86.53 \\
\hline Ort. & $15.25 \mathrm{~A}$ & $6.52 \mathrm{~B}$ & -57.24 & $1.01 \mathrm{C}$ & -93.37 & $1.17 \mathrm{~A}$ & $0.65 \mathrm{~B}$ & -44.44 & $0.16 \mathrm{C}$ & -86.32 \\
\hline
\end{tabular}

*Her bir sütunda farklı harflerle gösterilen uygulamalar arasında istatistiksel olarak fark varken $(\mathrm{p}<0.05)$, aynı harfle gösterilen uygulamalar arasında bir faklılık yoktur $(\mathrm{p}<0.05)$.

\section{Sonuç}

Tuz stresi altında yetiştirilen 20 farklı fasulye genotipinde yapılan çalışmada tüm parametreler bakımından genotipler arasında önemli farklılıkların olduğu ve genotiplerin tuz uygulamalarına birbirinden farklı tepkiler gösterdikleri ortaya çıkmıştır. Çalışmada hem uygulamalar hem de genotipler arasında istatistiksel olarak önemli farklılıkların olduğu gözlemlenmiştir. Uygulanan tuz konsantrasyonu artışına paralel olarak, sürgün boyu, yaprak sayısı, sürgün çapı, sürgün yaş ağırlığı, $\mathrm{K}, \mathrm{K} / \mathrm{Na}$ ve $\mathrm{Ca} / \mathrm{Na}$ oranının azaldığg; $\mathrm{Ca}$ ve $\mathrm{Na}$ besin elementi oranının 
arttığı belirlenmiş olmakla beraber, her iki tuz dozunda da önemli olumlu farklılıklar gösteren genotipler tespit edilmiştir.

Sürgün boyu parametresi yönünden, $25 \mathrm{Mm}$ tuz dozunda 5 ve 13 no'lu genotiplerde artışların meydana gelmesi, bitkilerin kök boylarında, $50 \mathrm{mM}$ tuz dozunda, yaprak sayısı bakımından ise $25 \mathrm{mM}$ tuz dozunda 5'no'lu genotipin en az etkilenen genotip olarak ortaya çıkması tolerant mekanizması açısından dikkat çeken bilgiler olmuştur.

Sürgün çapında 4 ve 17 no'lu genotiplerin $25 \mathrm{mM}$ tuz dozundan etkilenmemiş olmaları ve 4 no'lu genotipin 50 $\mathrm{mM}$ tuz dozunda da aynı etkiyi göstermesi bu genotip açısından önemli olarak değerlendirilmiştir. Sürgün yaş ağırlığı bakımından 2-4-7-8-11-12-17 ve 19 no'lu genotipler tuz dozlarından olumsuz etkilenmemişlerdir. Bu genotiplerin arasında olan ve daha önce de göze çarpan 4 no'lu genotipin $25 \mathrm{Mm}$ tuz dozunda Na içeriğinde artış göstermemesi önemli bir sonuç olarak saptanmıştır. Bitkilerin Ca içeriklerinde 13-16 ve 9 nolu genotiplerde azalışlar tespit edilmiş olup, daha önce de tolerant gösterebilen genotip olarak değerlendirilen 13 no'lu genotipin $\mathrm{Ca}$ içeriğinde de öne çıkması, bu genotipin tolerantlık açısından değerlendirilmesi gerektiğini ortaya koymuştur.

Ülkemizde gün geçtikçe daha da önemli bir sorun haline gelen tuzluluk probleminin çözümünde, tuzluluğa toleranslı çeşitlerin geliştirilebilmesi oldukça önem arz etmektedir. Bu bağlamda, yapmış olduğumuz çalışmadan elde edilen sonuçların değerlendirilerek, önemli bulunan genotiplerin farklı tuzluluk çalışmalarında da araştırılması, bu konudaki sslah çalışmalarına materyal anlamında katkı sunabileceği kanaatindeyiz.

\section{Teşekkür}

Bu makalenin oluşturulmasında kullanılan veriler, Van Yüzüncü Yıl Üniversitesi, Bilimsel Araştırma Projeleri Başkanlığı tarafından 2015-FBE-YL359 no'lu proje ile desteklenen yüksek lisans tezinden alınmıştır.

\section{Kaynaklar}

Aktaş H (2002). Biberde Tuza Dayanıklılığın Fizyolojik Karakterizasyonu ve Kalıtımı (Doktora tezi, basılmamış). ÇÜ, Fen Bilimleri Enstitüsü, Adana.

Ashraf M, Arfan M, Ahmad A (2003). Salt tolerance in okra: Ion relations and gas exchanges characteristics. Journal of Plant Nutrition, 26 (1): 63-79.

Ashraf M, Wu L (1994). Breeding for salinity tolerance in plants. Critical Reviews in Plant Sci., 13(1): 17-42.

Balkaya A (1999). Karadeniz Bölgesi'ndeki Taze Fasulye (Phaseolus Vulgaris L.) Gen Kaynaklarının Toplanması, Fenolojik ve Morfolojik Özelliklerinin Belirlenmesi ve Taze Tüketime Uygun Tiplerin Teksel Seleksiyon Yöntemi İle Seçimi Üzerinde Araştırmalar (Doktora tezi, basılmamış). Ondokuz Mayıs Üniversitesi, Fen Bilimleri Enstitüsü, Samsun.

Bozoğlu H, Sözen Ö (2007). Some agronomic properties of the local population of comman bean (Phaseolus vulgaris L.) of Artvin province. Turkish Journal of Agric. Forestry. (31): 327-334.

Çakmakcı T, Şahin Ü, Kuşlu Y, Kızıloğlu FM, Tüfenkçi Ş, Okuroğlu M (2016). Van İli Tarım Alanlarında Temiz ve Atık Su Kaynaklarının Yönetimi. Yüzüncü Yıl Üniversitesi Tarım Bilimleri Dergisi, 26(4):662-667.

Daşgan HY, Aktaş H, Abak K, Çakmak İ (2002). Determination of screening techni ques to salinity tolerance in tomatoes and investigation of genotype responses. Plant Science. (163): 695-703.

Debouba M, Goura H, Suzuki A, Ghorbel MH (2006). NaCl stress effects on enzymes involved in nitrogen assimilation pathway in Tomato "Lycopersicon Esculentum" seedling. Journal of Plant Physiology. (163): $1247-1258$.

Demir İ, Demir K (1996). Farklı tuz konsantrasyonlarının beş değişik fasulye çeşidinde çimlenme çıkış ve fide gelişimi üzerine etkileri. GAP 1. Sebze Tarımı Sempozyumu. 335-342.

Demir S (2009). Tuz Gölü Çevresinde Yetiştirilen Yöresel Kavun Populasyonunun (Koçhisar Kavunu) Tuza Tolerans Özellikleri Bakımından İncelenmesi (Yüksek lisans tezi, basılmamış). AÜ, Fen Bilimleri Enstitüsü, Ankara.

Düzgüneş O, Kesici T, Kavuncu O, Gürbüz F (1987). Araştırma ve Deneme Metotları. Ankara Üniversitesi, Ziraat Fakültesi Yayınları, 1021, 381, Ankara.

Güldüren Ş (2012). Kuzey Doğu Anadolu Bölgesi ve Çoruh Vadisi'nden Toplanan Bazı Fasulye (Phaseolus vulgaris L.) Genotiplerinin Tuza Toleransı (Yüksek lisans tezi, basılmamış) Atatürk Üniversitesi, Fen Bilimleri Enstitüsü, Erzurum.

Kant C (2008). Toprakta Oluşturulan Tuz Stresi Koşullarında Hümik Asit ve Hidrojen Uygulamasının Bazı Toprak Özellikleri ile Bazı Fizyolojik Bitki Parametreleri Üzerine Etkisi (Doktora tezi, basılmamış). AÜ, Fen Bilimleri Enstitüsü, Erzurum. 
Kaplan M, Kara R (2014). Silaj Sorgum'da bazı fizyolojik özelliklerin verim üzerine etkileri. Gaziosmanpaşa Üniversitesi Ziraat Fakültesi Dergisi, 31 (3): 20-31.

Kaya E (2011). Erken Bitki Gelişme Aşamasında Kuraklık ve Tuzluluk Streslerine Tolerans Bakımından Fasulye Genotiplerinin Taranması (Yüksek lisans tezi, basılmamış). ÇÜ, Fen Bilimleri Enstitüsü, Adana.

Kaymakanova M, Stoeva N (2008). Physiological reaction of bean plants (Phaseolus vulgaris L.) to salt stres. Gen. Appl. Plant Physiol, 34 (3-4): 177- 188.

Khalid M, Iqbal H, Tahir A, Ahmad A (2001). Germination potential of chickpeas (Cicer arietinumL.) under saline conditions. Pakistan Journal of Biological Sciences, 4 (4): 395-396.

Kıpçak S, Erdinç Ç (2016). Van Gölü Havzası'nda Yetiştirilen Bazı Fasulye (Phaseolus Vulgaris L.) Genotiplerinin Tuza Tolerans Seviyelerinin Belirlenmesi. Yüzüncü Yıl Üniversitesi Tarım Bilimleri Dergisi, 26 (3) : 421-429.

Kimbrough DE, Wakakuwa JR (1989). Acid digestion for sediments, sludges, soils, and solid wastes.Environmental Science \& Technology, 23 (7) : 898-900.

Koç S (2005). Fasulyelerde Tuzluluğa Tolerans Bakımından Genotipsel Farklılıkların Erken Bitki Gelişimi Aşamasında Belirlenmesi (Yüksek lisans tezi, basılmamış). ÇÜ, Fen Bilimleri Enstitüsü, Adana.

Kuşvuran Ş (2010). Kavunlarda Kuraklık Ve Tuzluluğa Toleransın Fizyolojik Mekanizmaları Arasındaki Bağlantılar (Doktora tezi, basılmamış). ÇÜ, Fen Bilimleri Enstitüsü, Adana.

Kuşvuran Ş (2011). Bamya (Abelmoschus esculentus L.)'da tuz stresine tolerans bakımından genotipsel farklılıklar ve tarama parametrelerinin araştırılması. Batı Akdeniz Tarımsal Araştırma Enstitüsü Derim Dergisi, 28(2) : 55-70.

Kuşvuran Ş (2012). Ion regulation in different organs of melon (Cucumis melo) genotypes under salt stress. International Journal of Agriculture and Biology, (14): 141-144.

Kuşvuran Ş, Ellialtıoğlu S, Abak K, Yaşar F. (2007). Responses of Some Melon (Cucumis Sp.) Genotypes to Salt Stress. Journal of Agricultural Sciences, Ankara Univ. Faculty of Agriculture. 13 (4): 395- 404.

Levitt J (1980). Responses of plants to environmental stresses volume II. (Physiological Ecology). Academic Pres, 365-490.

Lutts S, Kinet J.M, Bouharmont, J. (1996). NaCl-induced senescence in leaves of rice (Oryza sativa L.) cultivars differing in salinity resistance. Annals of botany, 78(3), 389-398.

Neves O.S.C, Carvalho J.G, Rodrigues C.R. (2004). Growth and Mineral Nutrition of Umbuzeiro Seedlings (Spondias Tuberosa Arr. Cam.) under Salt Stress in Nutrient Solution. CiEnc. Agrotec., 28: 997-1006.

Seemann JR, Critchley C (1985). Effects of salt stress on the growth, ion content, stomatal behaviour and photosynthetic capacity of a salt-sensitive species, Phaseolus vulgaris L. Planta, 164 (2) : 151-162.

Seymen B, Önder M (2015). Kuru fasulye (Phaseolus vulgaris L.) genotiplerinde tuzluluğun fide gelişimi üzerine etkisi. Selçuk Tarım Bilimleri Dergisi,2 (2) : 109-115.

Sözen Ö (2006). Artvin İli Yerel Fasulye (Phaseolus vulgaris L.) Populasyonlarının Toplanması, Tanımlanması ve Morfolojik Varyabilitesinin Belirlenmesi (Yüksek lisans tezi, basılmamış). Ondokuz Mayıs Üniversitesi, Fen Bilimleri Enst., Samsun.

Şalk A, Arın L, Deveci M, Polat S (2008). Özel Sebzecilik. Namık Kemal Üniversitesi, Ziraat Fakültesi. Tekirdağ. 185. (ISBN 978-9944-0786-0-3).

Takagi M, El-Shemy H.A, Sasakı S, Toyama S, Kanai S, Saneoka H, Fujita K (2009). Elevated CO2 Concentration Alleviates Salinity Stress in Tomato Plant. Soil and Plant Science, 59: 87-96.

Tiwari JK, Munshi AD, Kumar R, Pandey RN, Arora A, Bhat JS, Sureja AK (2010). Effect of salt stress on cucumber: $\mathrm{Na}^{+} \mathrm{K}^{+}$ratio osmolyte concentration, phenols and chlorophyll content. Acta physiologiae plantarum, 32 (1) : 103-114.

Yetişir H, Uygur V (2009). Plant growth and mineral element content of different gourd species and watermelon under salinity stres. Turkish Journal of Agriculture and Forestry, 33 (1) : 65-77. 